\title{
PRODUKSI IKAN JANTAN FUNGSIONAL (NEOMALE) UNTUK MEMBENTUK POPULASI BETINA HOMOGAMET DALAM INDUSTRI TELUR IKAN NILEM Osteochilus hasselti
}

\author{
Jojo Subagja"), Wartono Hadie"), dan Rudhy Gustiano") \\ ") Balai Penelitian dan Pengembangan Budidaya Air Tawar \\ ") Pusat Penelitian dan Pengambangan Perikanan Budidaya
}

(Naskah diterima: 20 Oktober 2014; Revisi final: 30 Oktober 2015; Disetujui publikasi: 9 November 2015)

\begin{abstract}
ABSTRAK
Ikan nilem (Osteochilus hasselti) dapat dijadikan ikan air tawar penghasil telur seperti halnya caviar, untuk itu, penyediaan ikan monosek betina sangat diperlukan. Benih ikan monoseks betina diperoleh dari persilangan ikan jantan fungsional dengan ikan betina normal. Penelitian ini bertujuan untuk mendapatkan teknik perbanyakan ikan jantan fungsional dengan sex reversal terhadap benih monoseks betina, menggunakan metiltestosteron (MT) melalui metode perendaman terhadap telur stadia bintik mata sampai umur empat hari dari menetas dengan dosis perendamam $500 \mu \mathrm{g} . \mathrm{L}^{-1}$ air, dan melalui oral dilakukan selama 21 hari dimulai pada larva umur empat hari, dosis hormon MT yang digunakan $500 \mu \mathrm{g} \cdot \mathrm{kg}^{-1}$ pakan dan diberikan tiga kali per hari. Ikan uji hasil perlakuan dipelihara hingga mencapai dewasa kelamin. Analisis gonad dini dilakukan terhadap 30 sampel dari masing-masing perlakuan terhadap benih ukuran 4-6 cm, dengan menggunakan pewarnaan aceto-carmin. Hasil pengamatan menunjukkan bahwa pembentukan jantan fungsional terhadap benih monoseks betina mencapai $86,67 \%$ dan $96,67 \%$ berturut-turut pada metode perendaman dan oral.
\end{abstract}

KATA KUNCI: ikan nilem, jantan fungsional, sex reversal, betina homogamet

ABSTRACT: Production of fungsional male for build female homogamet population to develop caviar industry of the silverminnow fish (Osteochilus hasselti). By: Jojo Subagja, Wartono Hadie, and Rudy Gustiano

The silver-sharkminnows fish (Osteochilus hasselti) is one of the freshwater fish that have ability to produce eggs as well as caviar, therefore the provision of female monosex fish are needed. Female monosex fish seeds were derived from a cross breeding neomales with normal females. This study aimed to obtain a propagation techniques of neomale fish with sex reversal to all females seed, using methyltestosterone (MT) through the immersion method at the eye-stage phase eggs until four days age of hatching with a MT dosage of $500 \mathrm{ig} . \mathrm{L}-1$ water, and orally administrated starting on the four days age larvae for 21 days, a hormone dosage of $500 \mathrm{ig} . \mathrm{kg}-1$ feed which were given three times per day. The tested fish were maintained until they reached sexual maturity. An analysis on the early gonad development was conducted on 30 samples of seed with sizing $4-6 \mathrm{~cm}$ by using aceto-Carmin colouration. The results showed that the formation of functional male against female monosex seed through immersion and oral method reached $86.67 \%$ and $96.67 \%$ respectively.

KEYWORDS: $\quad$ silver-sharkminnow fish, neomales, sex reversal, homogamet female

\section{PENDAHULUAN}

Industri telur ikan (caviar) berhubungan erat dengan tersedianya jumlah induk betina secara memadai. Terlebih lagi jika pemanenan telur harus mematikan induknya. Oleh karena itu, industri telur ikan harus mempertimbangkan kapasitas produksi, jumlah induk,

\# Korespondensi: Balai Penelitian dan Pengembangan Perikanan Budidaya Air Tawar. Jl. Raya Sempur No. 1, Bogor 16154, Indonesia. Tel.: + (0251) 8313200

E-mail: subagja.j@gmail.com laju kematangan gonad, dan laju pemanenan telur untuk memenuhi kebutuhan pasar.

Secara alami populasi ikan yang sifatnya heterogamet memiliki komposisi seimbang antara jantan dan betina. Menurut Zairin (2004), pada umumnya nisbah kelamin kelompok ikan teleost bernilai komersial menghasilkan rasio jantan dan betina yang tidak jauh berbeda dari angka 1:1, atas pertimbangan tersebut pembentukan induk diperlukan dalam skala besar agar jumlah induk betina memadai. 
Produksi ikan semua betina dapat ditempuh melalui kombinasi antara set kromosom (ginogenesis) dan dilanjutkan dengan jantanisasi menggunakan hormon metiltestosteron. Seperti yang telah dilakukan oleh Pongthana et al. (1999) untuk memproduksi ikan betina pada ikan tawes (Puntius gonionotus). Langkah pertama adalah pembentukan populasi ikan yang homozigot yaitu melalui teknik ginogenesis, kemudian benih ginogenetik diberi perlakuan hormon MT, benih hasil pengalihan kelamin inilah yang selanjutnya dilakukan uji-progeni, jantan fungsional diketahui apabila anakan hasil uji progeni menghasilkan semua ikan betina, serta metode langsung, dikenal dengan teknik sex reversal. Produksi ikan betina/ikan monoseks melalui perlakuan hormon secara langsung sukar dikontrol bila diaplikasikan kepada pembudidaya, dikhawatirkan media yang mengandung sisa-sisa hormon dapat mencemari lingkungan. Akhir-akhir ini peredaran $17 \alpha-$ metiltestosteron sudah mulai dibatasi karena diduga residu hormon tersebut menjadi salah satu bahan pencemar lingkungan (endocrine destruction agent) dan bersifat karsiogenik pada manusia (Phelps et al., 2001).

Penelitian tentang penggunaan hormon steroid untuk pengalihan kelamin telah banyak dilakukan antara lain untuk feminisasi dengan metode perendaman pada stadia larva ikan nila (Syam, 1997). Sutrisno (1996) menggunakan hormon $17 \alpha$-estradiol melalui perendaman pada stadia embrio ikan nila. Hasil penelitian tentang penggunaan hormon $17 \alpha$-estradiol dosis $400 \mu \mathrm{gL}^{-1}$ dengan metode perendam embrio dan larva ikan nilem dapat meningkatkan nisbah individu betina menjadi 78\%-94\% dibandingkan kontrol yang hanya 53\% (Subagja et al., 2006; 2007).

Hasil penelitian (Subagja et al., 2007) tentang jantanisasi ikan nilem menggunakan hormon metil testosteron, dengan dosis $500 \mu \mathrm{g} . \mathrm{kg}^{-1}$ pakan diberikan melalui oral menghasilkan populasi ikan nilem jantan, benih dipelihara hingga mencapai dewasa kelamin (menghasilkan sperma). Dari populasi ikan hasil sex reversal tersebut diduga terdapat individu jantan fungsional (jantan dengan kromosom xx). Uji progeni ikan jantan fungsional (neomale) telah dilakukan pada tahun 2008, terhadap 17 ekor dari populasi ikan nilem jantan hasil pengalihan kelamin tahun 2007. Fertilisasi dari masing-masing ikan jantan diuji terhadap sejumlah telur dari dua ekor betina normal (pooling gamet). Hasil uji progeni diperoleh sebanyak 10 ekor ikan jantan fungsional, anakan yang dihasilkan semua betina (Subagja \& Gustiano, 2010). Individu jantan fungsional yang telah teruji jumlahnya sangat terbatas, maka untuk penyediaan jantan fungsional dalam jumlah yang memadai perlu dikaji metode pengalihan kelamin yang efektif dan aplikatif.
Tujuan dari penelitian ini adalah untuk mendapatkan metode perbanyakan individu jantan fungsional ( $\left.0^{\prime} \mathrm{XX}\right)$ melalui teknik sex-reversal yang efektif, yaitu membandingkan antara teknik perendaman dengan teknik pemberian oral lewat pakan yang dilakukan terhadap anakan homogamet betina ikan nilem.

Produksi jantan fungsional secara massal dapat dilakukan, sehingga hasilnya dapat di distribusikan ke unit petani pembenih rakyat (UPR) dan BBI sebagai langkah awal untuk memproduksi anakan ikan betina yang pada tujuan akhirnya untuk produksi telur, serta keperluan calon induk untuk produksi benih.

\section{BAHAN DAN METODE}

\section{Pemeliharaan Induk}

Penelitian dilakukan di Laboratorium Basah Bioreproduksi Balai Penelitian dan Pengembangan Budidaya Air Tawar (BPPBAT) Bogor dan Instalasi Kolam Percobaan Cibalagung, Bogor. Pemeliharaan induk ikan dilakukan di Laboratorium BPPBAT Sempur, ikan jantan neomale dipelihara dalam wadah fiber glass volume 80 $\mathrm{L}$, sedangkan induk betina menggunakan wadah fiber glass volume $2 \mathrm{~m}^{3}$ yang dilengkapi dengan sistem resirkulasi biofilter. Pakan induk yang diberikan pakan formulasi, dengan protein $27 \%$ yang ditambahkan mikronutrien (Djajasewaka et al., 2005). Pakan harian sebanyak $2 \%$ dari bobot biomassa diberikan pada pagi dan sore hari.

\section{Pemijahan Buatan}

Pemijahan buatan dilakukan terhadap induk ikan nilem yang telah matang gonad dengan kriteria oosit telah mencapai modul diameter $1,1 \mathrm{~mm}$ (Subagja et al., 2006). Penyuntikan terhadap dua ekor betina terpilih dengan kisaran bobot antara $220 \mathrm{~g}$ dan $290 \mathrm{~g}$ menggunakan hormon ovaprim dengan dosis 0,4 mL. $\mathrm{kg}^{-1}$ bobot badan dan delapan ekor ikan jantan neomale (bobot rata-rata 54,4 $\pm 5,50 \mathrm{~g}$ ) dengan dosis $0,3 \mathrm{~mL} \cdot \mathrm{kg}^{-1}$ bobot ikan.

Pengalinan (stripping) ikan betina dilakukan setelah 11 jam dari penyuntikan. Telur dikeluarkan dengan cara mengurut bagian depan perut sampai ke bagian belakang (ke arah urogenetal) telur ditampung menggunakan waskom. Telur dari dua induk betina dibuahi dengan sperma dari delapan ekor jantan. Pengeluaran sperma secara kolektif dilakukan sebelum stripping ikan betina, selanjutnya sperma diencerkan hingga empat kali dengan larutan garam fisiologis $(\mathrm{NaCl} 0,9 \%)$, kemudian emulsi sperma disimpan pada suhu $5^{\circ} \mathrm{C}$ (Legendre, 1986), pada kondisi demikian sperma nilem dapat bertahan hidup hingga 8-12 jam dengan viabilitas $>80 \%$. 
Fertilisasi dilakukan terhadap sekitar 0,25 g telur kemudian dibuahi dengan $500 \mu \mathrm{L}$ sperma, telur yang telah terbuahi ditetaskan di dalam volume air $50 \mathrm{~L}$ pada akuarium ukuran $50 \mathrm{~cm} \times 50 \mathrm{~cm} \times 40 \mathrm{~cm}$, dengan sistem tergenang dan dilakukan pengaerasian.

\section{Perlakuan Hormon Sex Reversal}

Perlakuan hormon melalui metode perendaman dilakukan terhadap 190 butir telur yang ditempatkan pada wadah akuarium $(20 \mathrm{~cm} \times 20 \mathrm{~cm} \times 15 \mathrm{~cm})$, diisi air volume $4 \mathrm{~L}$ dengan tiga ulangan, perendaman dimulai sejak stadia bintik mata sampai dengan larva umur empat hari dari menetas dengan dosis metiltestosteron $500 \mu \mathrm{g} . \mathrm{L}^{-1}(2 \mathrm{mg} / 4 \mathrm{~L}$ air), kemudian untuk pemeliharaan selanjutnya larva dipindahkan ke akuarium volume $50 \mathrm{~L}$. Perlakuan hormon melalui oral dilakukan selama 21 hari dimulai dari larva umur empat hari sampai dengan umur 25 hari.

\section{Pemeliharaan Larva dan Benih}

Larva hasil perlakuan perendaman yang berumur 1-3 hari diberi pakan awal berupa nauplii Artemia, selanjutnya diberikan pakan berbentuk tepung (starter No. 1) hingga ikan berukuran bobot 0,5 g.ekor ${ }^{-1}$. Pemeliharaan selanjutnya dilakukan di dalam hapa hijau (mesh size $1,5 \mathrm{~mm}$ ) berukuran $1 \mathrm{~m} \mathrm{x} 1 \mathrm{~m} \times 1 \mathrm{~m}$ yang dipasang di kolam ukuran $200 \mathrm{~m}^{2}$. Pemeliharaan berlangsung hingga empat bulan, selama masa pemeliharaan ikan diberikan pakan buatan berbentuk butiran halus dengan kadar protein $35 \%$ sebanyak 3\%5\% dari bobot biomassa.

\section{Deteminasi Gonad}

Pemeliharaan anakan berlangsung sampai umur empat bulan, nisbah kelamin dilakukan dengan metode preparat ulas pada primordia gonad ikan menggunakan larutan acetocarmin. Teknik pembuatan preparat ulas adalah sebagai berikut: ikan uji sebanyak 60 ekor dimatikan dengan cara menusuk pada bagian rongga otak menggunakan jarum ose, kemudian dilakukan pembedahan pada bagian perut. Isi perut diangkat, primordia gonad tampak pada kiri kanan gelembung renang berupa benang halus berwarna transparan/bening kemudian diangkat menggunakan pinset, diletakkan di atas "slide glass" dan dihaluskan. Jaringan yang telah halus ditetesi acetocarmin dan ditutup dengan cover glass kemudian dikeringanginkan, setelah sedikit mengering diamati di bawah mikroskop pada pembesaran lensa 10 x 40 . Nisbah kelamin ditentukan dengan menghitung persentase dari sampel yang diamati.

\section{Analisis Data}

Pengamatan determinasi kelamin dilakukan dengan observasi deskriptif, kemudian dihitung perbandingan jantan betina, parameter yang diamati meliputi daya tetas, serta sintasan benih.

\section{HASIL DAN BAHASAN}

\section{Daya Tetas Telur pada Perlakuan Perendaman} dan Tanpa Perendaman

Pemijahan induk betina normal dengan jantan fungsional (neomale) menghasilkan keturunan

Tabel 1. Daya tetas telur ikan nilem hasil pembuahan dengan sperma ikan jantan neomale pada perlakuan perendaman saat embrio, dengan hormon metiltestoteron (A) dan tanpa perlakuan hormon (B)

Table 1. Hatching rate of the silver shark-minnow eggs fertilized with neomale sperm immersed at the embryo time treated of methyltestosteron (A) and without treatment (B)

\begin{tabular}{lccc}
\hline $\begin{array}{c}\text { Nomor akuarium } \\
\text { Aquarium number }\end{array}$ & $\begin{array}{c}\text { Sperma } \\
(\text { Sperm })(\mathrm{mL})\end{array}$ & $\begin{array}{c}\text { Bobot telur } \\
\text { (Weight of } \text { eggs })(\mathrm{g})\end{array}$ & $\begin{array}{c}\text { Daya tetas telur } \\
\text { (Hatching rate) }(\%)\end{array}$ \\
\hline A1 & 0.5 & 0.256 & 87.1 \\
A2 & 0.5 & 0.246 & 91.1 \\
A3 & 0.5 & 0.235 & 91.5 \\
Rata-rata \pm SD $($ Average $\pm S D)$ & & $0.25 \pm 0.01$ & $89.9 \pm 2.43$ \\
\hline B1 & 0.5 & 0.235 & 79.3 \\
B2 & 0.5 & 0.244 & 88.3 \\
B3 & 0.5 & 0.248 & 90.4 \\
Rata-rata \pm SD $($ Average $\pm S D)$ & & $0.24 \pm 0.01$ & $86.0 \pm 5.89$ \\
\hline
\end{tabular}

Keterangan (Note):

A: Perendaman MT saat embrio (MT submersion at the embryo time)

B: Tanpa perendaman, larva dipergunakan untuk perlakuan oral (Without submersion, the larvae used for oral treatment) 
homogametik betina. Bobot induk betina yang disuntik rata-rata $250 \mathrm{~g}$, dan menghasilkan telur $37 \mathrm{~g}$. Telur dibuahi sperma dari jantan neomale yang dikoleksi dari delapan ekor, daya tetas rata-rata 87,88 $\pm 4,53 \%$; di mana daya tetas pada metode perendaman ratarata $89,9 \pm 2,43 \%$; dan tanpa perendaman $86,0 \pm$ $5,897 \%$.

Konsentrasi metiltestosteron sebanyak 500 mg.L $\mathrm{L}^{-1}$ dengan pelarut etanol tidak memengaruhi daya tetas telur meskipun tidak sebaik pada perendaman hormon estradiol yang mencapai daya tetas rata-rata $95,51 \%$ (Subagja et al., 2008).

Mortalitas yang terjadi selama umur dua minggu pertama tertera pada Gambar 1. Dua hari setelah menetas terdapat larva yang abnormal (deformitas) dan pada hari ketiga larva tersebut mati. Jumlah larva yang abnormal berkisar $1 \%-2 \%$ dari larva yang menetas. Dari hasil pengamatan selama 14 hari, terlihat bahwa puncak kematian larva terjadi pada umur 10-12 hari pada perlakuan perendaman. Penyebab kematian pada larva ikan nilem belum dapat dipastikan, namun pada larva ikan patin kisaran umur demikian berada pada tahapan organogenesis dan akan sempurna pada umur 14 hari (Legendre et al., 2000). Oleh karena itu, masa kritis di mana timbul kematian yang banyak pada larva ikan nilem hingga umur 14 hari diduga sedang dalam tahap organogenesis, terlebih pada larva dengan perlakuan hormon metode oral kematian larva mencapai 7,9\%; namun setelah masa tersebut terlewati kematian larva hampir jarang dijumpai.

\section{Determinasi Kelamin Ikan Nilem}

Gonad ikan nilem berjumlah sepasang terletak pada bagian kiri dan kanan rongga perut menempel di bawah tulang vertebrata. Gonad berbentuk memanjang dan bermuara di lubang genital. Gonad pada stadia ini masih berwarna putih, bakal gonad jantan dari hasil pengamatan visual berbentuk benang berwarna putih diselimuti lemak, sedangkan bakal gonad betina berbentuk benang sedikit melebar, berwarna merah muda.

Observasi histologis terhadap perbedaan antara gonad jantan dengan betina terlihat pada Gambar 2 . Gonad jantan dari observasi preparat ulas tampak bakal spermatozoa yang berbentuk titik-titik bulat berkelompok (Gambar 2b), sementara gonad betina terlihat calon sel telur yang sudah memperlihatkan bentuk membulat seperti terlihat pada Gambar 2a. Dari hasil pengamatan preparat terhadap 60 sampel, mayoritas menunjukkan bakal gonad jantan (Gambar 2b). Secara visual bakal gonad betina (oogonia) tersusun rapih dengan kisaran diameter 100-200 $\mu \mathrm{m}$, sementara bakal gonad jantan (Gambar 2b) secara visual terlihat seperti koloni-koloni yang terselubung oleh dinding pembatas halus, setiap koloni berukuran antara $200-400 \mu \mathrm{m}$.

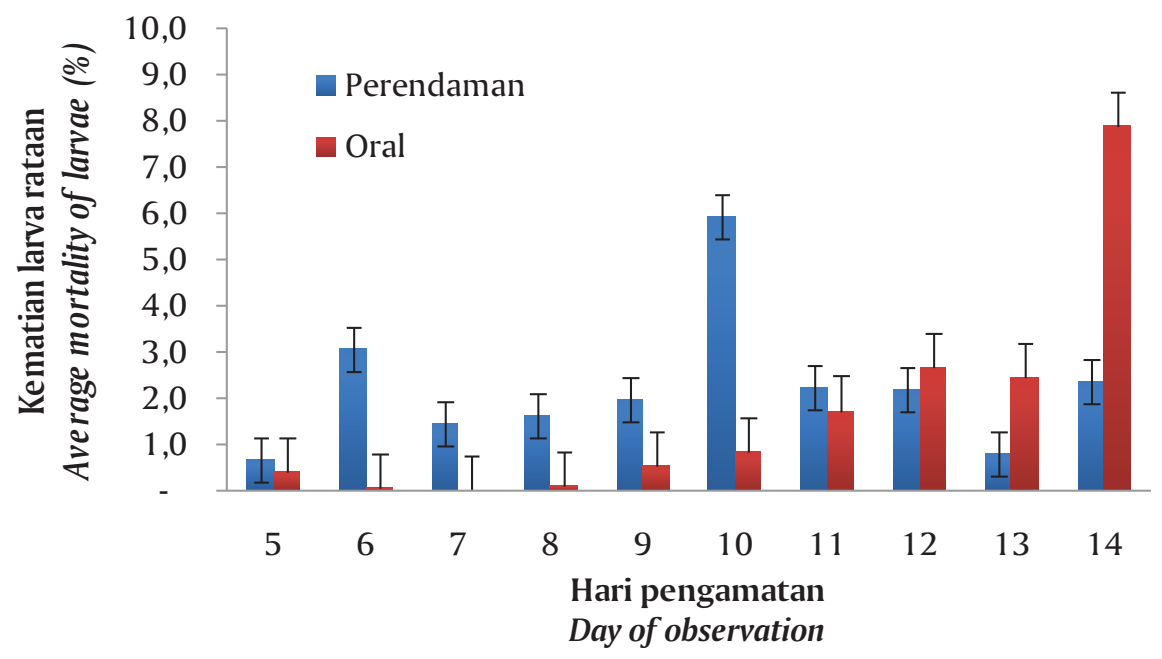

Gambar 1. Mortalitas harian larva ikan nilem pada perlakuan metiltestosteron dengan metode perendaman dan metode oral melalui pakan selama perkembangan larva sampai dengan umur 14 hari

Figure 1. Daily mortality of fish larvae of silver minnow through methyltestosterone immersion and oral feed method during larvae development until day $14^{\text {th }}$ 

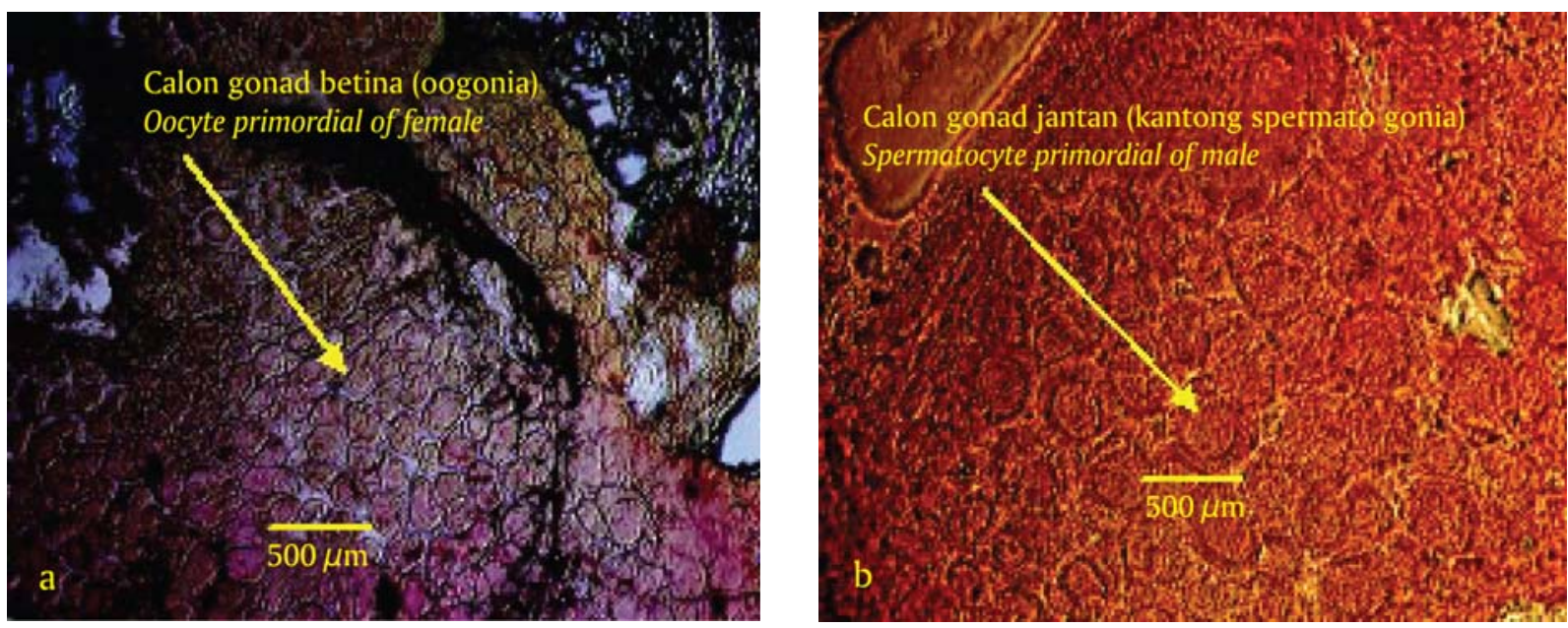

Gambar 2. Bakal gonad ikan betina dan Jantan hasil preparat ulas aceto-charmin pada individu berukuran bobot 3-5 g; (a) calon gonad betina, (b) calon gonad jantan

Figure 2. Aceto-carmin smear preparation of primordial gonad of male and female from the individual of 3-5 $\mathrm{g}$ body weight; (a) oosite primordial of female, (b) spermatosite primordial of male

Dari 30 sampel individu pada masing-masing perlakuan yang diuji diperoleh nisbah jantan : betina sebesar 26:4 (jantan 86,67\%) dari perlakuan perendaman, dan nisbah jantan : betina sebesar 29:1 (jantan 96,67\%) dari perlakuan oral. Dari hasil tersebut diketahui bahwa perlakuan pemberian MT melalui pakan (oral) sekitar 10\% lebih tinggi dibandingkan dengan melalui perendaman. Hal tersebut dikarenakan pada pemberian secara oral memiliki jumlah hormon yang cukup dan tersedia selama masa pemaparan, sedangkan pada cara perendaman kemungkinan jumlah hormon yang terserap belum mencukupi untuk proses pengarahan kelamin dari betina ke jantan. Melihat kisaran hasil betina yang besar, diduga bahwa dosis dan waktu pemaparan singkat saat perlakuan hormon (perlakuan perendaman) menyebabkan proses diferensiasi kelamin belum optimal, sehingga masih memungkinkan terjadinya perubahan struktur fungsi jaringan primodia gonad kembali ke fungsi semula (Masaru et al., 1998).

Hasil uji progeni dari perkawinan jantan neomale dengan betina normal dari kedua perlakuan tidak berbeda, yaitu menghasilkan $100 \%$ betina, hasil tersebut telah diuji pada percbaan performa betina ikan nilem hasil pemijahan antara betina normal dengan jantan fungsional (Subagja et al., 2010). Hasil percobaan ini memberikan peluang bahwa perlakuan pembuatan neomale memakai cara oral melalui pakan lebih dianjurkan. Populasi jantan neomale yang lebih banyak diperoleh dengan cara oral, sehingga populasi betina

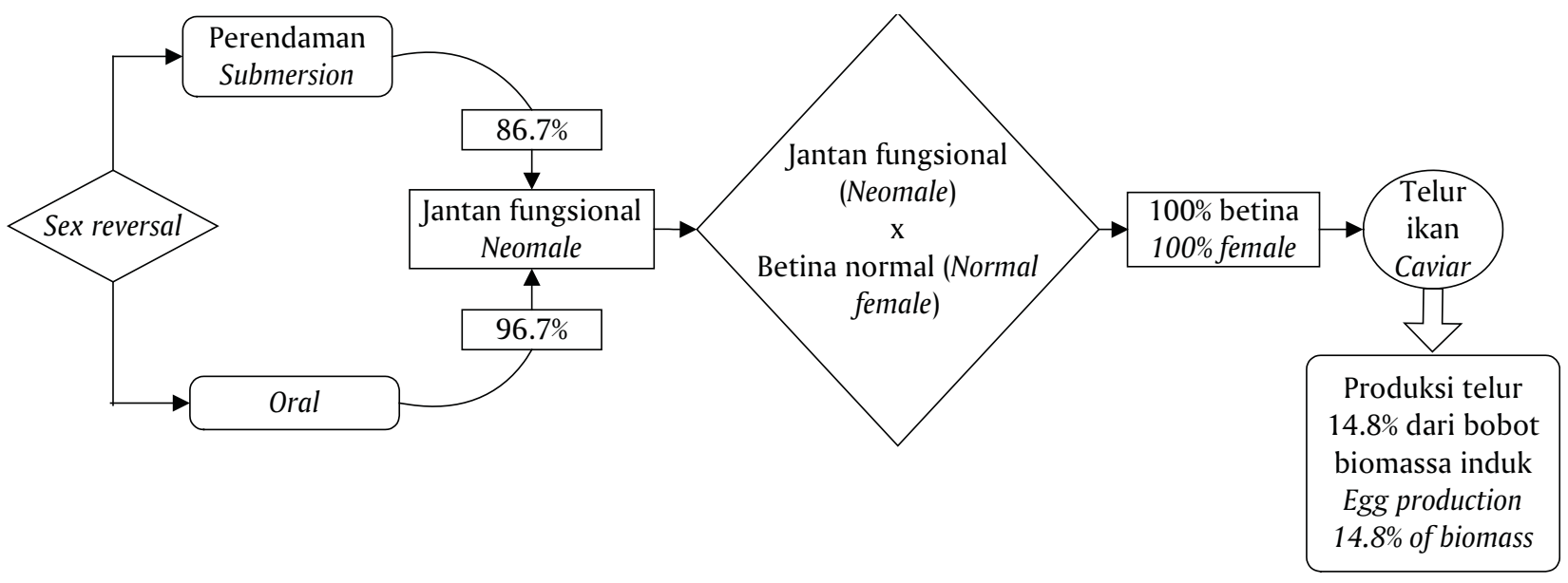

Gambar 3. Implementasi hasil penelitian jantan fungsional untuk menghasilkan progeni betina $100 \%$ yang selanjutnya untuk produksi telur

Figure 3. Research implementation of neomale to produce mass female for the egg fish industry 
homogamet sebagai keturunannya juga akan lebih banyak, dengan demikian kecukupan untuk induk betina penghasil telur dapat disediakan secara memadai.

\section{Implementasi Hasil Penelitian}

Penerapan hasil penelitian ini dapat dituangkan dalam bagan alir kegiatan produksi (Gambar 3) mulai pembentukan individu neomale hingga menghasilkan betina yang akan menghasilkan telur. Implementasi hasil penelitian ini adalah untuk industri telur ikan yang dapat dipasarkan secara langsung ataupun dalam bentuk olahan. Untuk membuat skala usaha yang menguntungkan, maka diperlukan kelengkapan data tentang kapasitas reproduksi induk betina ikan nilem.

Fekunditas ikan nilem yang dihasilkan dari penelitian ini adalah $37 \mathrm{~g}$ telur dari induk dengan bobot $250 \mathrm{~g}$. Proporsi bobot telur dibandingkan bobot induk mencapai $14,8 \%$. Hasil lain menyebutkan bahwa fekunditas ikan nilem meliputi $18 \%-20 \%$ dari bobot induk betina dengan bobot $150 \mathrm{~g}$ atau sebanyak 20.000-40.000 butir telur dan jika menjadi benih berkisar 15.000-30.000 ekor dari setiap pasang induk (PBIAT, 2007). Dari hasil penelitian dapat dilihat kapasitas produksi induk betina normal untuk menghasilkan telur dengan asumsi produktivitas ikan betina hasil produksi "all female" sama dengan betina normal. Pola tersebut selanjutnya dibuat ekstrapolasi dalam menyusun suatu rencana industri telur ikan nilem. Dalam bagan alur (Gambar 3) faktor kuncinya adalah keberhasilan memproduksi neomale, yang selanjutnya untuk produksi telur.

\section{KESIMPULAN}

Penggunaan hormon metiltestosteron melalui metode perendaman dan oral dapat menghasilkan individu jantan neomale sebesar 86,67\% dan 96,67\%. Perkawinan antara jantan neomale dengan betina normal menghasilkan $100 \%$ betina sehingga dapat diaplikasikan untuk industri telur ikan.

\section{Saran}

Pengamatan benih all female hingga mencapai dewasa dan matang gonad masih perlu dilakukan percobaan agar diketahui performanya untuk dibandingkan dengan betina hasil pemijahan dengan jantan normal.

\section{UCAPAN TERIMA KASIH}

Ucapan terima kasih disampaikan kepada: Balai Riset Perikanan Budidaya Air Tawar, yang telah membiayai kegiata riset ini. Sdr. Bei Abasari, Sirodiana, Wawan Setiawan, M. Kutub (Teknisi BPPBPAT), yang telah membantu pelaksanaan kegiatan. Sdr. Edi Farid yang telah membantu pembuatan preparat ulas gonad

\section{DAFTAR ACUAN}

Djajasewaka.H., J. Subagja; A. Widiyati, R. Samsudin dan Winarlin. (2005). Pengaruh Kadar Protein Terhadap Produksi dan Kualitas Telur Induk Ikan Nilem (Osteochilus Hasselti). Seminar hasil penelitian Balai Riset Perikanan Budiaya Air Tawar, Bogor.

Legendre. M, J. Slembrouck, J. Subagja, and, A. H. Kristanto, O. Komarudin, Sudarto and Maskur. (2000). Pangasius jambal : A New Candidate Species for Fish Culture in Indonesia, IARD Journal. $22: 1-14$.

Legendre. M. (1986). Seasonal changes in sexual maturity and fecundity, and hCG-induced breeding of the catfish, Heterobranchus longifilis Val. (Clariidae), reared in Enbrie lagoon (Ivory Coast). Aquaculture, 55, 201-213.

Masaru ,N., Kobayashi, T., Chang, X.T., \& Nagahama, Y. (1998). Gonadal sex differentiation in teleost fish. Journal Experiment Zoology, 281, 362-372.

PBIAT Muntilan. (2007). Budidaya ikan nilem (Osteochilus hasselti). Pusat Budidaya Ikan Air Tawar, Muntilan. Jogjakarta, $12 \mathrm{hlm}$.

Phelps, R., Sanchez, W.C., Couturier, G.M., Abiado, M., \& Dabrowski, K. (2001). Studies on fate of methiltestosterone and its metabolites in tilapia and onthe use of phutochemicals as an alternative method to produce a monosex population of tilapia. Reproduction Control Research I (10RCRI) /Experiment/ Mexico. Pdarcrsp.orst.edu/pubs/ workplns/wp10/10RCRI.html-27k.

Pongthana, N., Penman, D.J., Baoprasertkul, P., Hussain M.G., Shahidul, M.I., Powell, S.F., \& McAndrew, B.J. (1999). Monosex female production on the silver barb (Puntius gonoinotus Bleeker). Aquaculture, 173, 247-256.

Subagja, J., Gustiano, R., \& Djajasewaka, H. (2006). Penentuan dosis hormon steroid dan teknik pemberian untuk feminisasi ikan nilem (Osteochilus hasselti). Laporan Hasil Penelitian BPPBAT Bogor, $12 \mathrm{hlm}$.

Subagja, J., Gustiano, R., \& Djajasewaka, H. (2007). Penyediaan ikan nilem (Osteochilus hasseltii C.V.) betina untuk mendukung produk olahan di Jawa Barat. ProsidING Seminar Internasional Perikanan 2007 "Quality Management System, New Technology and International Marceting of Fish and Seafood Product".Pusat Penelitian dan Pengabdian Masyarakat (P3M). STP Jakarta, HLM. 202-214.

Subagja, J., Sukadi, M.F., \& Gustiano, R. (2008). Seleksi jantan fungsional melalui uji keturunan pada ikan nilem (Osteochilus hasseltii C.V.). Sainteks, XV(3), 149-154. 
Subagja,. J., \& Gustiano, R. (2010). Uji keturunan jantan hasil pengalihan kelamin pada ikan nilem (Osteochilus hasselti C.V.). Omni-Akuatika, IX(11), 69-74.

Subagja, J., Setijaningsih, L., \& Gustiano, R. (2010). Keragaan pertumbuhan ikan nilem betina "all female" hasil persilangan jantan fungsional dengan betina normal. Laporan Hasil Penelitian Balai Penelitian dan Pengembangan Budidaya Air Tawar, Bogor. Disampaikan dalam Seminar hasil Riset 2010.

Sutrisno, E. (1996). Pengaruh lama waktu pemberian hormon 17Â-estradiol secara oral terhadap nisbah kelamin ikan nila merah (Oreochromis niloticus). Skripsi. Fakultas Perikanan dan Ilmu Kelautan, Institut Pertanian Bogor.

Syam, Y. (1997). Pengaruh perendaman hormon 17Â-estradiol dengan dosis berbeda pada larva umur 7 hari selama 18 hari terhadap nisbah kelamin ikan nila merah (Oreochromis sp.). Skripsi. Fakultas Perikanan dan Ilmu Kelautan, Institut Pertanian Bogor.

Zairin, M.Jr. (2004). Sex-reversal memproduksi benih ikan jantan atau betina. Penebar Swadaya. Jakarta, $96 \mathrm{hlm}$. 
